ISSN 2072-4292

www.mdpi.com/journal/remotesensing

Article

\title{
Mapping Secondary Forest Succession on Abandoned Agricultural Land with LiDAR Point Clouds and Terrestrial Photography
}

\author{
Natalia Kolecka $^{1, *}$, Jacek Kozak ${ }^{1}$, Dominik Kaim ${ }^{1}$, Monika Dobosz ${ }^{1}$, Christian Ginzler ${ }^{2}$ \\ and Achilleas Psomas ${ }^{2}$
}

1 Department of GIS, Cartography and Remote Sensing, Institute of Geography and Spatial Management, Jagiellonian University, Kraków 30-387, Poland;

E-Mails: jkozak@gis.geo.uj.edu.pl (J.K.); dkaim@gis.geo.uj.edu.pl (D.K.); mdobosz@gis.geo.uj.edu.pl (M.D.)

2 Swiss Federal Research Institute WSL, Zuercherstrasse 111, 8903 Birmensdorf, Switzerland; E-Mails: christian.ginzler@wsl.ch (C.G.); achilleas.psomas@wsl.ch (A.P.)

* Author to whom correspondence should be addressed; E-Mail: nkolecka@gis.geo.uj.edu.pl; Tel.: +48-12-644-5323; Fax: +48-12-664-5385.

Academic Editors: Nicolas Baghdadi and Prasad S. Thenkabail

Received: 14 April 2015 / Accepted: 17 June 2015 / Published: 25 June 2015

\begin{abstract}
Secondary forest succession on abandoned agricultural land has played a significant role in land cover changes in Europe over the past several decades. However, it is difficult to quantify over large areas. In this paper, we present a conceptual framework for mapping forest succession patterns using vegetation structure information derived from LiDAR data supported by national topographic vector data. This work was performed in the Szczawnica commune in the Polish Carpathians. Using object-based image analysis segments of no vegetation, and sparse/dense low/medium/high vegetation were distinguished and subsequently compared to the national topographic dataset to delineate agricultural land that is covered by vegetation, which indicates secondary succession on abandoned fields. The results showed that $18.7 \%$ of the arable land and $40.4 \%$ of grasslands, that is $31.0 \%$ of the agricultural land in the Szczawnica commune, may currently be experiencing secondary forest succession. The overall accuracy of the approach was assessed using georeferenced terrestrial photographs and was found to be $95.0 \%$. The results of this study indicate that the proposed methodology can potentially be applied in large-scale mapping of secondary forest succession patterns on abandoned land in mountain areas.
\end{abstract}


Keywords: forest succession; land cover; LiDAR; multiresolution segmentation; terrestrial photography

\section{Introduction}

Quantification of secondary forest succession is critical for the sustainable management of forestry and agricultural resources, biodiversity monitoring and climate change modeling [1]. For more than 100 years, Europe has experienced an increase in forest cover [2-4] due to afforestation and forest expansion on abandoned agricultural land. The latter has played a significant role in land cover changes in Europe over the past several decades [5-8], particularly in marginal mountain areas [9-14]. The Polish Carpathians have experienced a gradual decline of agricultural areas since World War II that accelerated after the collapse of the Soviet Union and related socio-economic transformations [15-18] as well as a significant increase in fallow or abandoned agricultural land with visible signs of forest succession. For instance, the recent Polish agricultural census $[19,20]$ reported a notable decrease in agricultural land area between 2002 and 2010 in the Carpathian provinces of Małopolska and Podkarpacie (by 16.5\% and 14.9\%, respectively). Ostafin [21] showed that between $14.9 \%$ and $46.6 \%$ of the agricultural land in nine communes in the Beskid Średni Mountains showed signs of abandonment with visible secondary forest succession, and Kaim [22] documented the importance of the land abandonment process for the long-term increase in forest cover in the Polish Carpathians using repeat terrestrial photography. Secondary forest succession on abandoned land in the Polish Carpathians typically occurs at high elevations, on steep slopes, and near forest edges [17]. Because of the small farm and land parcel sizes, secondary forest succession on abandoned land is a spatially dispersed process $[17,23,24]$.

Secondary forest succession on abandoned land can be easily observed and mapped over small areas in the field $[25,26]$ but is difficult to monitor with remote sensing because the related changes in land cover are subtle, dispersed and difficult to discriminate from other land uses, such as gardens, orchards, tree nurseries or even parks [17,27]. Several studies have used optical imagery at various spatial resolutions to document land abandonment and forest succession in different regions [15,16,18,24,28-30]. In particular, Kuemmerle et al. [16] mapped farmland abandonment from 1986 to 2000 with an overall accuracy of $91 \%$ using a support vector machine (SVM)-based approach with Landsat TM/ETM+ imagery. Using similar methods, Hostert et al. [18] analyzed farmland changes related to land abandonment from 1986 to 1992 (the period after the Chernobyl disaster) and after 1992 (post-Soviet period); their change map had an overall accuracy of 80\% [14].

Airborne LiDAR (Light Detection and Ranging) data have been shown to have the potential to quantify vegetation cover and three-dimensional (3D) vegetation structures [31-36]. Forest successional stages and regeneration patterns have been mapped with sufficiently high accuracy in several LiDAR-based studies [25,32,37,38]. Many of them, however, were seeking for the best casespecific solution, even at the expense of laborious production of LiDAR-derived layers. For example, Falkowski et al. [25] mapped six stages of succession in a mountainous conifer forest using the Random Forest procedure with a variety of LiDAR-derived metrics. Similarly, LiDAR-derived indices 
were used by Ewijk et al. [32] to characterize four stages of forest succession in a mixed forest. Martinuzzi et al. [37] classified forest types and delineated the status of forest succession by applying classification-tree techniques to LiDAR-derived metrics, Landsat imagery, and Shuttle Radar Topography Mission (SRTM) elevation models, and found significantly better performance with the LiDAR-based analysis. Asmare [38] explored the role of LiDAR data in supporting sustainable community forest management and forest certification in Nepal. Kane et al. [26] demonstrated that if field measurements are not available, forest successional stages can be accurately characterized by LiDAR data. Recently, object-based image analysis (OBIA; [39-41]) has been used to process LiDAR data and particularly LiDAR-derived canopy height models (CHM), to delineate individual trees [42-44] and forest stands [31,45,46] and to discriminate between different land cover types [47]. Several studies have integrated LiDAR data with other sources to increase the accuracy of vegetation mapping at various scales [48-50] and find the best case-specific solutions. Overall, many studies have demonstrated the outstanding capacity of LiDAR data to monitor various stages of forest succession. However, while many studies have examined forest structure and dynamics with these data, less attention has been paid to mapping secondary forest succession on abandoned fields over large areas, though the results of some small-scale studies are available [51].

Terrestrial photographs play an important role in landscape research [52] because of their ability to illustrate landscape changes [30,53-56]. For example, visual analysis of repeated terrestrial photographs in several areas of the Polish Carpathians demonstrated their potential in assessing long-term, gradual landscape changes that are related to forest succession and expansion on agricultural land [22]. While attempts to support the analysis of terrestrial photographs by developing georeferencing software emerged in the mid-1990s [57-60], the developed products did not meet the user requirements in terms of flexibility and user-friendliness [61]. The recently developed AVALMAPPER software allows the creation of an orthoimage from a terrestrial (oblique) photograph using photogrammetric and computer vision rules and has been successfully applied in the manual vectorization of avalanche areas [62-64]. Bozzini et al. and Bozzini et al. [61,65] proposed the WSL Monoplotting Tool, which allows different features to be measured directly on a previously georeferenced terrestrial photograph. The software has been used to map old channels for wood transport and past flood damage [61], to reconstruct the states of the Rhone glacier since the 19th century [66,67], and to quantify the evolution of vegetation cover [65]. These software developments may increase the potential of using terrestrial photographs in landscape change research through improved integration with other georeferenced data.

The present amount of secondary forest succession in the Polish Carpathians is still unknown. In many cases, land owners are not aware of how much of their land has been overgrown with shrubs and trees, and census data are not consistent with the ground conditions because they are not updated [68]. Update of the census would be a long and laborious process, but of high importance for sustainable development and spatial management of the region. The integration of new types of data acquisition technologies, such as LiDAR and georeferenced terrestrial photographs, may improve the mapping efficiency and accuracy of secondary forest succession dynamics in diverse mountain environments. The aim of our study was therefore (1) to develop a robust methodology to map secondary forest succession patterns on abandoned lands in the Polish Carpathians based primarily on LiDAR data that are acquired through airborne laser scanning (ALS) and (2) to test the ALS classification results with 
georeferenced terrestrial photographs. In addition, because our aim was to provide wide area mapping of secondary forest succession in Poland, we limited our methodology to standard ALS data that are available within the national coverage in Poland.

\section{Materials and Methods}

Our goal was to develop an OBIA-based automated classification procedure of ALS data that would allow mapping of secondary forest succession on abandoned lands. Thus, central to our interest was agricultural land that was covered with vegetation typical of secondary forest succession-particularly tall herb communities, shrubs, bushes, and single young trees - that progressively occupy former arable land [68,69]. OBIA was selected for two reasons: it facilitated the reduction of the raw ALS data, and the spatial segments that are delineated on the ALS data represent real world objects because succession patterns reflect field and parcel boundaries. We tested our approach with georeferenced terrestrial photographs assuming that the terrestrial photographs will facilitate ground truthing of the classification while ensuring sufficiently high accuracy. Ancillary topographic data were also used to eliminate various land use types that might contain vegetation similar to secondary forest succession but that had a completely different legal or land use status.

The general approach consisted of the following steps: (1) Derivation of gridded vegetation indices based on LiDAR point clouds; (2) Segmentation of the raster data; (3) Classification of image segments based on vegetation indices; (4) Analysis of vegetation patterns for the selected land use classes that were extracted from the national topographic dataset and delineation of secondary forest succession areas; (5) Verification of the mapped secondary forest succession using georeferenced terrestrial photographs.

\subsection{Study Area}

The study area was the Szczawnica commune, which is located in the Polish Carpathians in the Małopolska Province at the Slovak-Polish border (Figure 1a). The town of Szczawnica has been a popular spa resort since the mid-19th century due to the presence of many mineral springs, the favorable climatic conditions and the unique surroundings. The commune, which has an area of $87.90 \mathrm{~km}^{2}$ [70], is located within the Grajcarek catchment and is surrounded by ridges of the Beskid Sądecki (1266 m a.s.1.) and the Małe Pieniny Mountains (1050 m a.s.1.). The mountainous terrain with steep slopes and deep valleys covers approximately three quarters of the commune area. According to the agricultural census data [19], forests (68\%) and agricultural land (28\%) cover most of the commune's area. Approximately half of the forest belongs to the State Forests National Forest Holding.

Since the mid-20th century, the area has been subject to dynamic changes in land use. The eastern part of the commune was depopulated after World War II, and the former croplands were mostly collectivised and converted to pastures or forests [71]. Agricultural activities, and particularly sheep grazing, declined after 1990, which initiated forest succession on abandoned lands as well as afforestation (Figure 1b) [71-73]. 
a
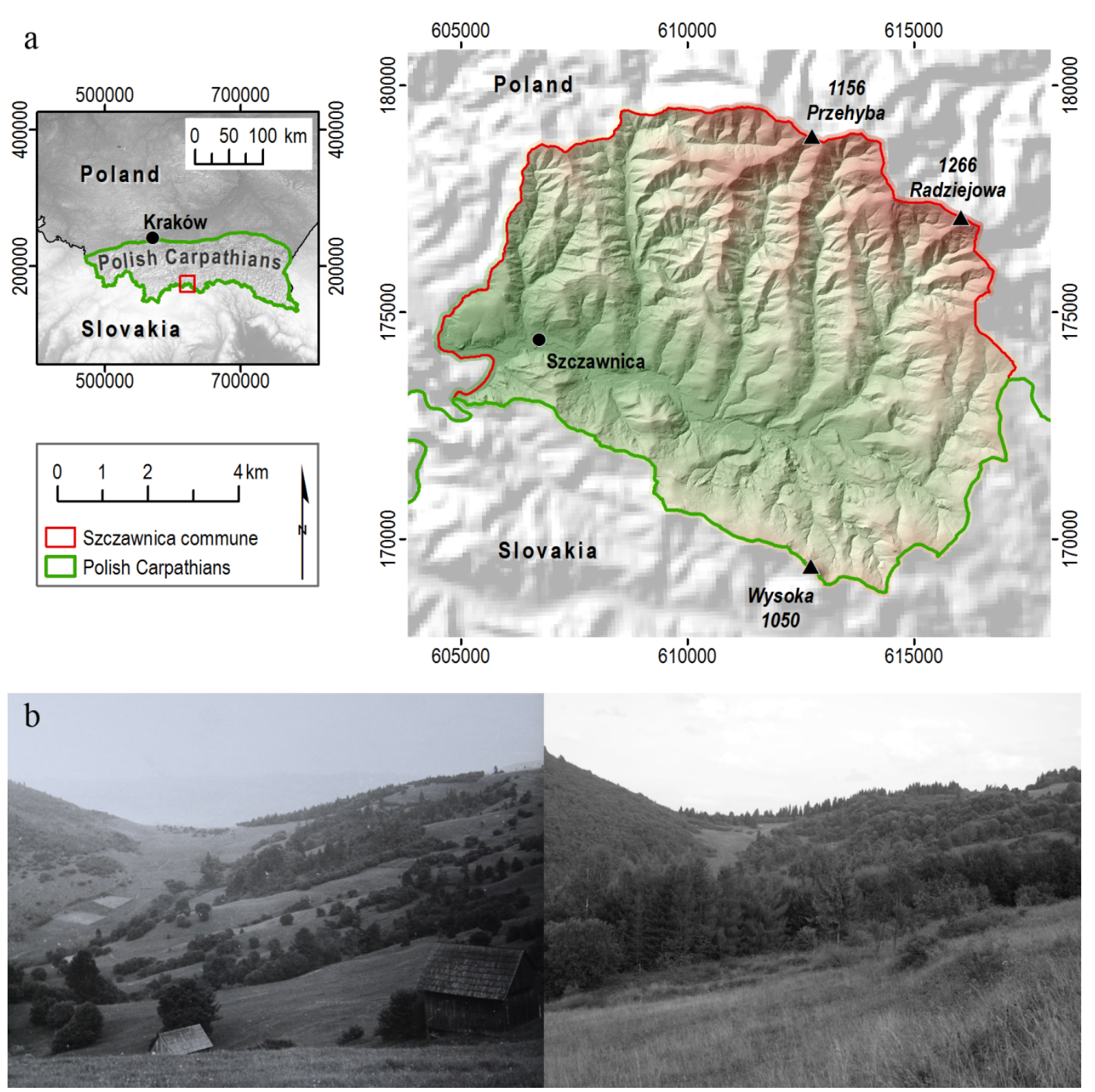

Figure 1. (a) The study area of the Szczawnica commune; (b) repeat terrestrial photographs from 1975 (left, courtesy and permission for the archive photograph: Pieniny National Park) and 2009 (right) showing changes in land cover in the Małe Pieniny Mountains (Source: Kaim [22]).

\subsection{Data}

LiDAR point clouds were acquired on 15 October 2012 within the national ISOK (Informatyczny System Osłony Kraju) project [74] at a minimum density of 4 points $/ \mathrm{m}^{2}$. The data were collected in a multi-return mode with a maximum of five return echoes registered for each emitted pulse and a field of view of less than $\pm 25^{\circ}$. The accuracy assessment showed vertical and horizontal root mean square errors (RMSEs) of $0.10 \mathrm{~m}$ and $0.23 \mathrm{~m}$, respectively [75]. Within the ISOK project, the data were already classified according to the American Society for Photogrammetry and Remote Sensing standards [76] into ground (class 2), low (3), medium (4) and high (5) vegetation, buildings (6), low points (7), model key-points (8), water (9) and others. Data classification in ISOK was performed 
automatically, but the classification process was followed by a visual inspection and manual correction of misclassified points. The automatic classification of the ground points was performed using the progressive densification filtering algorithm developed by Axelsson [77], which produces high accuracy results [78]. Threshold values of $0.4 \mathrm{~m}$ and $2 \mathrm{~m}$ were set to distinguish low, medium and high vegetation. The acceptable error for the ground point classification was $1 \%$, whereas the threshold for the other classes was 6\% [74]. The pre-processed LiDAR data with classified features were received from CODGiK (Centralny Ośrodek Dokumentacji Geodezyjnej i Kartograficznej; the Main Center of Geodetic and Cartographic Documentation in Poland) in a series of 92 1:2500 scale map sheets in LAS format.

The national database of topographic objects (Baza Danych Obiektów Topograficznych 10k; BDOT10k) represents accurate and up-to-date topographic information of the terrain in Poland [79]. It was completed in 2013 and is based on complementary datasets (e.g., cadaster, records of infrastructure networks, State Boundary Register, orthophotomaps, and digital terrain models) and public resort records with a level of detail that corresponds to 1:10,000 scale topographic maps. BDOT10k consists of feature classes that are grouped into nine categories (hydrography, communication, utilities, land cover, buildings and infrastructure, land use complexes, protected areas, administrative units, and others). The continuous-coverage land cover layer includes twelve feature classes: water bodies, residential land, forest and woodland, shrubland, permanent crops, grassland and arable land, transport units, wasteland, open spaces, mine sites, waste dumps, and other industrial areas. The land use complexes layer includes additional information on sports and recreational facilities, such as parks, botanical gardens, zoos, sport centers and summer houses. The BDOT10k data were received from CODGiK in geodatabase format.

Terrestrial photographs used for the accuracy assessment can be divided into two sets, including photographs (1) taken with the intention of being used in the research, and (2) taken incidentally during mountain hiking trips with no intention for use in the accuracy assessment. Photographs from the first set were taken during field work on 31 May 2014 and 18 September 2014 with a Nikon D5100 camera (16 Mpix matrix) equipped with an 18-105 mm zoom lens. Photographs from the second set were taken on 10 August 2010, 23 May 2014 and 19 July 2014 with different digital cameras with different matrix sizes and focal lengths. From the collection of approximately 250 photographs, the 13 best examples taken in late spring and summer, with leaf-on conditions (1 from 10 August 2010, 2 from 31 May 2014, 5 from 19 July 2014, and 5 from 18 September 2014) were selected for further processing by visual inspection. The prerequisite for the selection was that the photograph showed an illustrative portion of the study area in a clear and undisturbed way. The usefulness of each photo was determined mainly by the perspective, lighting, distance to the photographed objects and presence of objects (ground control points) that would enable georeferencing. The camera matrix size and focal length were also taken into account. The selected photographs were distributed regularly over the study area. They provided views of opposite slopes at several distances to ensure a good perspective with as few obstacles in the foreground as possible (Figure 2).

RGB orthophotomaps with a spatial resolution of $0.25 \mathrm{~m}$ that were computed from aerial images acquired in 2009 were received from CODGiK. They were used as auxiliary data for georeferencing the terrestrial photographs and for the visual inspection of the land cover classification. 
a
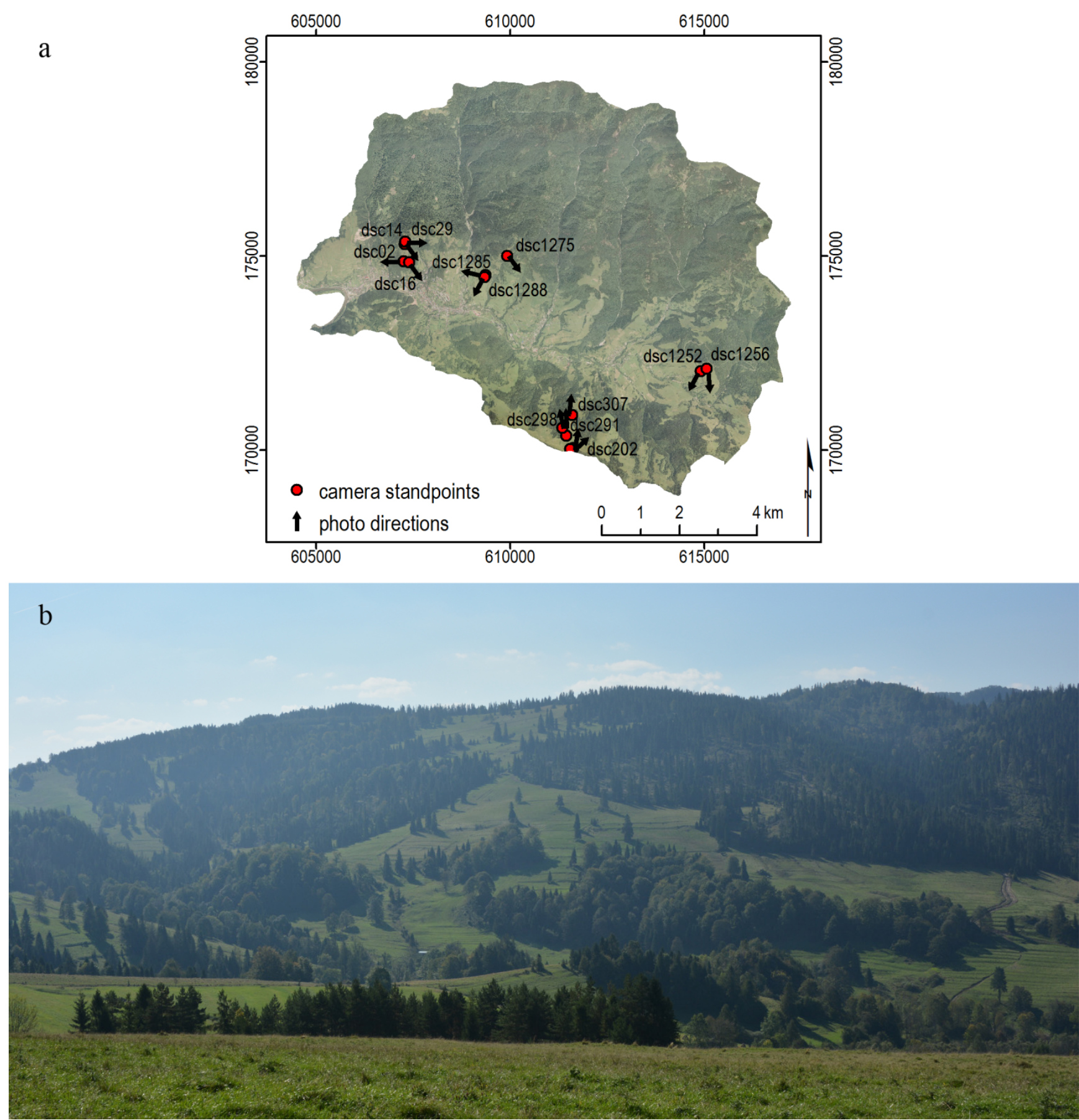

Figure 2. (a) Camera standpoints and directions of the selected terrestrial photographs that were used for the accuracy assessment (basemap source: CODGiK); (b) example of the terrestrial photographs that were used in the accuracy assessment (dsc1256, 18 September 2014).

\subsection{ALS Processing}

Based on field observations and previous studies [80], we decided to stratify the land cover types using vegetation height and vegetation canopy cover, which is the proportion of the ground that is covered by the vertical projection of the tree crowns or vegetation [81]. The vegetation height was derived from the Vegetation Height Model (VHM), which represents the difference in elevation 
between the Digital Terrain Model (DTM) and the Digital Vegetation Model (DVM). The DTM and DVM were interpolated from the ALS point clouds and had resolutions of $1 \mathrm{~m}$.

The DTM represented the mean elevation of the ground points (ASPRS class 2), whereas the DVM represented the maximum elevation of the vegetation points (ASPRS classes 3, 4, 5); if vegetation was not recorded, the DVM represented the bare ground (ASPRS class 2). The vegetation cover (VC) was computed as the percentage of first returns from the medium and high vegetation (ASPRS classes 4 and 5) compared to the total number of first returns, which is a modified formula proposed by Smith et al. [82] who used all returns instead of first ones. VC was computed with a spatial resolution of $2 \mathrm{~m}$ to ensure the identification of more than one point within each cell. Nevertheless, some cells contained no data, especially within water bodies; they were assigned a value of zero. The LiDAR point clouds were processed in the ESRI ArcGIS 10.1 [83] and ERDAS Imagine [84] software.

For the entire study area, the VHM and VC layers were segmented and classified using the eCognition software [85], which offers a multiresolution segmentation that consecutively merges pixels or existing image objects based on the local homogeneity criterion $[39,85]$. In segmentation process, he VHM and VC layers were equally weighted and the output resolution was set to the higher value of both layers $(1 \mathrm{~m})$. To create most meaningful objects reflecting the heterogeneity of vegetation patterns the segmentation scale parameter was set to 70 using the estimation of scale parameter (ESP) tool [86,87]. The ESP tool iteratively segments the image with fixed increments of the scale parameter and calculates the local variance (LV) of the object heterogeneity for each scale and the rate of change in LV (ROC-LV) across the scales. Local ROC-LV maxima indicate statistically significant scales at the image level [87]. The other two segmentation parameters (shape and compactness) were set to 0.3 and 0.5 , respectively using a trial-and-error approach, as there are no automatic procedures facilitating their calibration. Here we used also our previous experience from tests carried out in various sites located in the Polish Carpathians. Through combining scale, shape and compactness parameters we emphasized importance of differences in values of vegetation height and canopy cover and considered also the tendency of land cover objects in anthropogenic landscapes to have regular shapes. The relevance of the selected segmentation parameters was approved by visual inspection of the created objects against the input layers and the orthophotomap.

The classification of the segments was performed in two successive steps (Figure 3). The mean VC values of the segments were used to stratify the segments into three classes: no vegetation (mean $\mathrm{VC}<2 \%$ ), sparse vegetation $(2 \%<$ mean $\mathrm{VC}<20 \%)$ and dense vegetation (mean $\mathrm{VC}>20 \%$ ). The no vegetation class included mostly bare ground, water and urban areas. The sparsely vegetated areas were grasslands or arable land with single shrubs and trees, and the dense vegetation was represented by areas that were completely covered by shrubs and trees, such as forests. The latter two classes were divided using the segment mean VHM into low (mean VHM $<1 \mathrm{~m})$, medium $(1 \mathrm{~m}<$ mean $\mathrm{VHM}<10 \mathrm{~m}$ ) and high vegetation (mean VHM $>10 \mathrm{~m}$ ). These thresholds were determined in test studies of randomly sampled segments using classification and regression trees (CART) [80]. CART is a recursive partitioning method that analyzes data via a tree-building algorithm and determines a set of if-then logical conditions to accurately predict or classify cases [88]. 


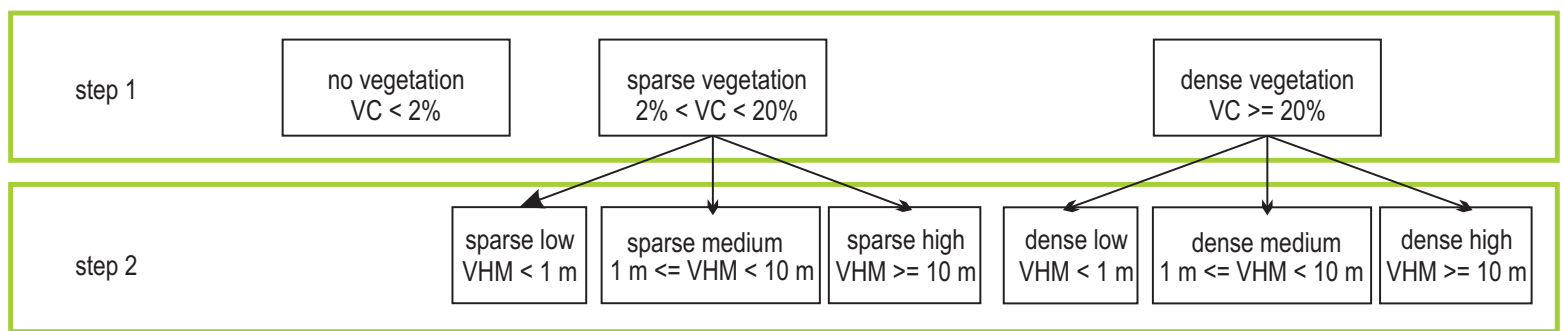

Figure 3. Rules of the vegetation classification based on ALS data.

While the object-based classification of ALS data shows the actual patterns of vegetation (actual land cover), BDOT10k includes additional information about formal and functional land use and land cover which helped to confine the analysis to forest and agricultural areas. First, various land use and land cover types in BDOT10k like water bodies, residential land, transport units, wasteland, open spaces, mine sites, waste dump, other industrial areas, as well as sports and recreational facilities (3.5\% of the Szczawnica commune) were excluded from the analysis. In this way, forest and agricultural mask was created. Next, results of the object-based classification of ALS data and the BDOT10k forest and agricultural mask were juxtaposed to determine where the land formally classified as agricultural (arable lands and grasslands) was covered by vegetation indicating secondary succession on abandoned fields, meadows and pastures. A simple map overlay of the ALS-derived vegetation map and the BDOT10k land use and land cover vector layers was applied. A crosstabulation matrix was computed to provide detailed information about the correspondence between the two data sets. The distribution of secondary forest succession areas within the agricultural land was then analyzed using the ESRI ArcGIS 10.1 software (ESRI, Redlands, CA, USA).

\subsection{Accuracy Assessment}

A critical issue in land cover change research is accuracy assessment [89]. Originating from traditional validation methods for pixel-based classifications, many OBIA classification results have been assessed by point-based sampling, although object-based strategies are highly recommended [90,91]. A polygon that represents a meaningful and homogenous patch of land is more suitable for accuracy assessments of maps that are produced with OBIA [89,92,93]. In general, the spatial and thematic properties of the output segments are compared to reference features, such as those obtained from manual vectorization or surveyed on the ground $[93,94]$.

For the accuracy assessment, segments that represent no vegetation, sparse vegetation, and dense vegetation classes were selected as long as they were entirely within the BDOT10k grassland or arable land classes and they had an area greater than $1000 \mathrm{~m}^{2}$. A total of 4699 candidate segments were selected, which represents $88 \%$ of the grassland and arable land area.

To be used for the accuracy assessment, the terrestrial photographs needed to be accurately georeferenced; in particular, the position and orientation of the camera and the focal distance had to be reproduced. The photographs were processed with the WSL Monoplotting Tool [61,65]. At least six control points were measured in each photograph. The real world coordinates were manually obtained from the DTM and orthophotomaps, and the accuracies of the georeferencing process was analyzed. The accuracy of the georeferencing of the terrestrial photographs was expressed in image pixels as the 
mean of the distances between the original and re-calculated coordinates of the control points within each photograph. The errors ranged from 2.7 pix to 13.7 pix, and the mean error for all of the photographs was $5.4 \pm 3.1$ pix, which represents distances of $2 \mathrm{~m}$ to $10 \mathrm{~m}$ in the field depending on a photograph. The terrain pixel sizes were calculated according to the photogrammetric formula for scale determination [95]. Large errors occurred if a control point was located much closer to or much further from the camera than the other points, such as beyond the area of interest. The error-prone control points were sometimes necessary to correctly orientate the photograph due to the instability of the algorithm implemented within the WSL Monoplotting Tool.

The selected segments were then overlaid on the georeferenced terrestrial photographs using the WSL Monoplotting Tool, and the segment boundaries were back-projected onto the appropriate terrestrial photograph. For the accuracy assessment, 989 segments were retained after rejecting those that had less than $50 \%$ of their area visible in the photograph or were partially or completely occluded by trees or buildings. These segments were relatively evenly distributed from west to east over the entire study area (Figure 4); however, no segments were located in the northern part of the study area, which has high elevations and is mainly covered by forest. The sample included 529 no vegetation segments, 141 sparse low vegetation segments, 172 sparse medium vegetation segments, 135 dense medium vegetation segments, and 12 dense high vegetation segments. There were no sparse high or dense low vegetation segments in the samples, but they represent $5.5 \%$ of the grasslands and arable lands in the study area and $0.2 \%$ of the area of all of the candidate segments. The sample size allowed a $2.8 \%$ margin of error at a $95 \%$ confidence level $[89,96]$.

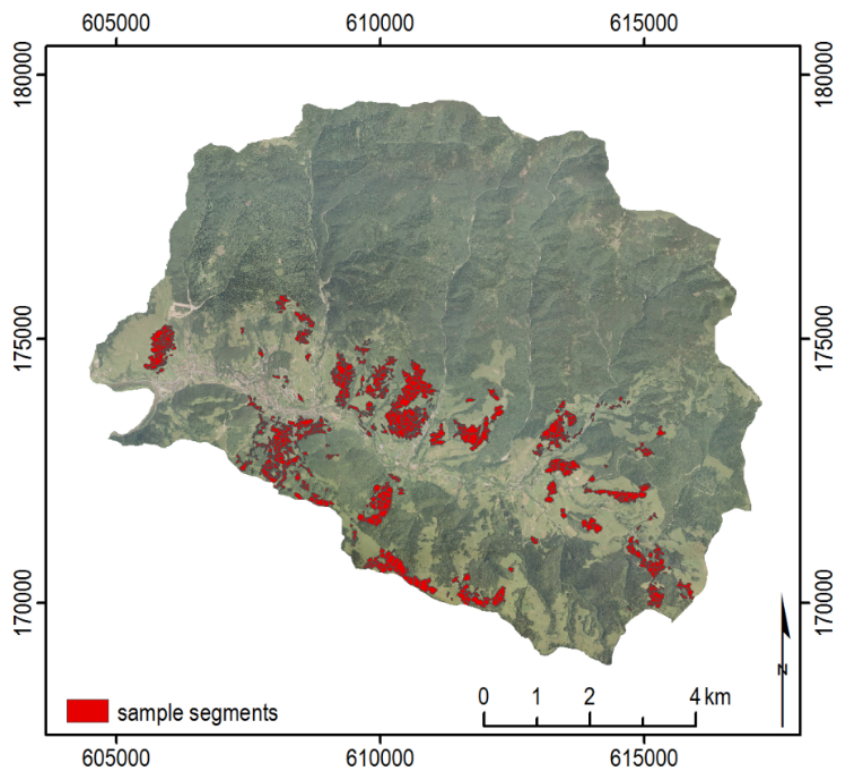

Figure 4. Distribution of the sample reference segments over the study area (basemap source: CODGiK).

The segments were then evaluated against the terrestrial photographs using the object fate analysis (OFA) method, which involves both spatial and thematic accuracy [91,97,98]. Following the recommendation of Schöpfer and Lang [97], the spatial relationships between the segments and the ground truth data were categorized by the following states of transition: good (falling completely within the 5-10 m buffered outline of the land cover patch (S1), which corresponded to 1-2 pixels in 
the photographs, considering distance from the camera to the specific location in terrain, and matrix size) and expanding (exceeding the boundary with a 10-20\% overlap (S2)). We also assessed the thematic accuracy, which represents if the segments were correctly or incorrectly classified (referred to as $\mathrm{T} 1$ or $\mathrm{T} 2$, respectively). The segments were assessed visually and subsequently attributed with appropriate scores that represent the spatial and thematic accuracy. The overall accuracy (OA) was determined as the percentage of segments that were classified correctly both spatially and thematically. The individual class accuracies were expressed by the producer's (PA) and user's (UA) accuracies.

\section{Results}

\subsection{Object-Based Classification of LiDAR Data}

The study area was divided into 36,934 segments, each of which was assigned one of the seven vegetation classes (Figure 5 and Table 1). Areas of no vegetation covered $18.2 \%$ of the analyzed area and were mainly concentrated at higher elevations than the built-up area, on the lower slopes, and near the Małe Pieniny ridge to the south. Dense high and medium vegetation and sparse medium vegetation covered $52.2 \%, 16.9 \%$ and $8.6 \%$ of the analyzed area, respectively, and represented the large forest stands of the Beskid Sądecki and Pieniny ranges. The remaining classes (dense low vegetation, sparse low and high vegetation) covered only very small percentages of the commune. The average segment size was $2294 \mathrm{~m}^{2}$; however, the sizes of the different classes varied (Table 1). The no vegetation class had the largest segments, whereas the patches of dense low vegetation were significantly smaller than the others. The sparse low, dense medium and high vegetation patches exceeded the average segment size, while the sparse medium and high vegetation patches were smaller than the average.

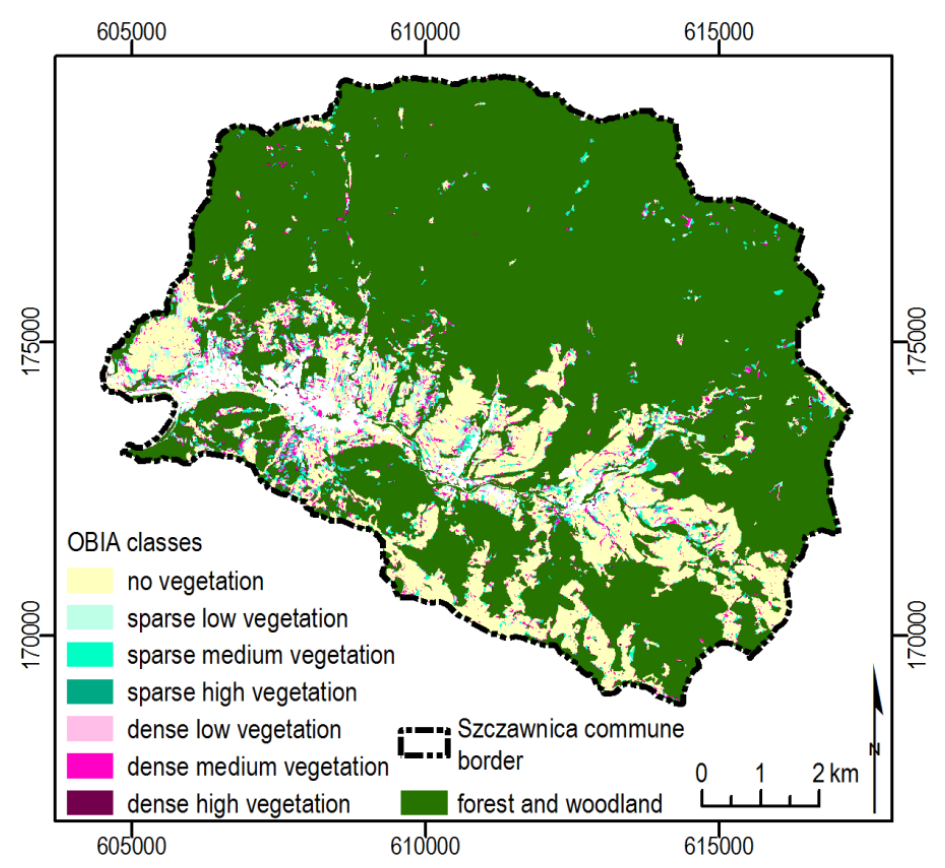

Figure 5. Results of the object-based classification within the agricultural class of BDOT10k. 
Table 1. Characteristics of the object-based image analysis (OBIA) segmentation and classification within the agricultural class of BDOT10k.

\begin{tabular}{ccccc}
\hline OBIA Class & $\begin{array}{c}\text { Number of } \\
\text { Classified Objects }\end{array}$ & $\begin{array}{c}\text { Mean Area of } \\
\text { Classified Objects } \\
{\left[\mathbf{m}^{2}\right]}\end{array}$ & $\begin{array}{c}\text { \% of } \\
\text { Analyzed Area }\end{array}$ & $\begin{array}{c}\text { Number of Classified Objects in } \\
\text { Sample Used for the } \\
\text { Accuracy Assessment }\end{array}$ \\
\hline no veg. & 2936 & 5254 & 18.21 & 529 \\
sparse low veg. & 917 & 2465 & 2.67 & 141 \\
sparse medium veg. & 4821 & 1510 & 8.59 & 172 \\
sparse high veg. & 1137 & 999 & 1.34 & 0 \\
dense low veg. & 30 & 957 & 0.03 & 0 \\
dense medium veg. & 8823 & 1625 & 16.92 & 135 \\
dense high veg. & 18270 & 2423 & 52.24 & 12 \\
Total & 36934 & & 100 & 989 \\
\hline
\end{tabular}

\subsection{Relationships between the BDOT10k and LiDAR-Based Classification}

Of the analyzed area, $74.8 \%$ was in the BDOT10k forest and woodland class, most of which were classified as dense high (51.6\%) and dense medium (14.5\%) vegetation (Table 2). The BDOT10k classes of arable land and grassland, which made up $11.0 \%$ and $14.1 \%$ of the analyzed area, respectively, contained mostly the no vegetation class. Within these two classes, however, we found also large areas of sparse and dense low, medium and high vegetation. They covered $18.7 \%$ of the arable land and $40.4 \%$ of the grasslands, which is $31.0 \%$ of the agricultural land in the Szczawnica commune, and could be labelled as secondary forest succession areas (Figure 6). The remaining BDOT10k class of shrubland did not exceed $0.5 \%$ of the study area and contained mostly sparse or dense, low, medium or high vegetation $(>94 \%)$.

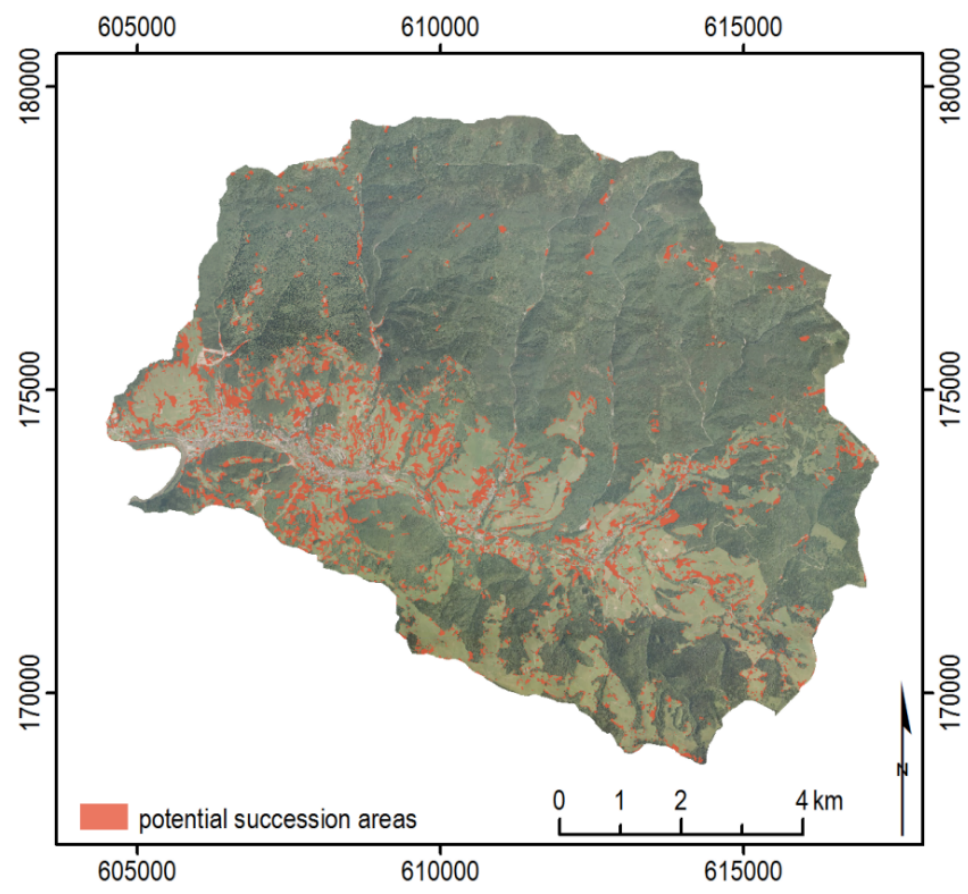

Figure 6. Secondary forest succession areas (Basemap Source: CODGiK). 
Table 2. Cross tabulation of the object-based classification results and selected BDOT10k classes. "\% of SA" represents the percentage of OBIA classes within the study area, and "\% of BDOT10k" represents the percentage of OBIA classes within the selected BDOT10k classes.

\begin{tabular}{|c|c|c|c|c|c|c|c|c|c|}
\hline \multirow{2}{*}{$\begin{array}{c}\text { BDOT10k Class } \\
\text { OBIA Class }\end{array}$} & \multicolumn{2}{|c|}{ Arable Land } & \multicolumn{2}{|c|}{ Grassland } & \multicolumn{2}{|c|}{ Forest, Woodland and Grove } & \multicolumn{2}{|c|}{ Shrubland } & \multirow{2}{*}{$\begin{array}{c}\text { Total } \\
\text { \% of } \\
\text { SA } \\
\end{array}$} \\
\hline & $\begin{array}{c}\% \text { of } \\
\text { SA }\end{array}$ & $\begin{array}{c}\text { \% of } \\
\text { BDOT10k }\end{array}$ & $\begin{array}{c}\% \text { of } \\
\text { SA }\end{array}$ & $\begin{array}{c}\text { \% of } \\
\text { BDOT10k }\end{array}$ & $\begin{array}{c}\% \text { of } \\
\text { SA }\end{array}$ & $\begin{array}{c}\text { \% of } \\
\text { BDOT10k }\end{array}$ & $\begin{array}{c}\% \text { of } \\
\text { SA }\end{array}$ & $\begin{array}{c}\text { \% of } \\
\text { BDOT10k }\end{array}$ & \\
\hline no vegetation & 8.9 & 81.3 & 8.4 & 59.6 & 0.9 & 1.2 & 0.0 & 5.7 & 18.2 \\
\hline sparse low veg & 0.8 & 6.7 & 1.4 & 10.0 & 0.5 & 0.7 & 0.0 & 10.4 & 2.7 \\
\hline sparse medium veg & 0.5 & 4.9 & 2.0 & 14.2 & 6.0 & 8.0 & 0.0 & 25.7 & 8.5 \\
\hline sparse high veg & 0.0 & 0.0 & 0.0 & 0.1 & 1.3 & 1.8 & 0.0 & 0.0 & 1.3 \\
\hline dense low veg & 0.0 & 0.1 & 0.0 & 0.1 & 0.0 & 0.0 & 0.0 & 0.0 & 0.0 \\
\hline dense medium veg & 0.6 & 5.6 & 1.7 & 12.1 & 14.5 & 19.4 & 0.1 & 57.2 & 16.9 \\
\hline dense high veg & 0.2 & 1.4 & 0.6 & 3.9 & 51.6 & 68.9 & 0.0 & 1.0 & 52.4 \\
\hline TOTAL & 11.0 & 100 & 14.1 & 100 & 74.8 & 100 & 0.1 & 100 & 100 \\
\hline sum of vegetated area & 2.1 & 18.7 & 5.7 & 40.4 & 73.9 & 98.8 & 0.1 & 94.3 & 81.8 \\
\hline
\end{tabular}

A total of $56.9 \%$ of the high/medium/low sparse or dense vegetation segments within the arable land and $71.1 \%$ of these segments within the grasslands were adjacent to forests. Of all of the segments with signs of secondary forest succession on agricultural land, $62.4 \%$ were adjacent to forests. The remaining segments were mainly located along the cart tracks and streams and at balks, where they formed linear features. They were also located near the residential area, where they could represent urban vegetation, and in the fields as single trees or groups of trees and/or shrubs.

\subsection{Accuracy Assessment of the Extended National Database}

All of the sample segments were assigned good spatial accuracy (S1) because no segment extension was identified. A total of 940 segments were thematically classified correctly (Table 3), which represents an overall accuracy of $95.0 \%$. The producer's accuracies for the no vegetation, sparse low, sparse medium, dense medium and dense high vegetation classes were all greater than $85 \%$, while the user's accuracies were greater than $90 \%$ except for the sparse low vegetation $(88.7 \%)$. For rare classes such as dense low vegetation, where only 3 segments were assessed, the accuracy was $0 \%$ because all of the segments were classified incorrectly as sparse low vegetation. The accuracy of the class that represents sparse high vegetation was not determined due to the lack of sample segments used for the accuracy assessment, and the accuracy of the class that represents dense low vegetation was not determined due to the lack of reference objects that are visible on terrestrial photographs.

\section{Discussion}

This study was intended to design and test a robust approach for mapping forest succession patterns in a mountainous area of the Polish Carpathians using LiDAR-derived vegetation structure information with object-based analysis supported by national topographic vector data. The OBIA concept was shown to be applicable for extracting real-world features, such as land cover patches, where the level of detail can be adjusted to the desired scale of the derived objects $[41,86,99]$. 
Table 3. Confusion matrix for the object-based classification expressed in terms of the numbers of segments.

\begin{tabular}{|c|c|c|c|c|c|c|c|c|c|}
\hline $\begin{array}{c}\text { Reference } \\
\text { Map } \\
\end{array}$ & $\begin{array}{l}\text { No } \\
\text { Veg } \\
\end{array}$ & $\begin{array}{c}\text { Sparse } \\
\text { Low Veg } \\
\end{array}$ & $\begin{array}{c}\text { Sparse } \\
\text { Medium Veg } \\
\end{array}$ & $\begin{array}{c}\text { Sparse } \\
\text { High Veg } \\
\end{array}$ & $\begin{array}{c}\text { Dense } \\
\text { Low Veg } \\
\end{array}$ & $\begin{array}{c}\text { Dense } \\
\text { Medium Veg } \\
\end{array}$ & $\begin{array}{c}\text { Dense } \\
\text { High Veg } \\
\end{array}$ & Total & $\begin{array}{c}\text { Users } \\
\text { Accuracy } \\
\end{array}$ \\
\hline No veg & 514 & 10 & 3 & 2 & & & & 529 & 97.2 \\
\hline Sparse low veg & & 125 & 13 & & 3 & & & 141 & 88.7 \\
\hline Sparse medium veg & & 9 & 158 & & & 5 & & 172 & 91.9 \\
\hline Dense low veg & & & & & 0 & & & 0 & 0.0 \\
\hline Dense medium veg & & & 3 & & & 131 & 1 & 135 & 97.0 \\
\hline Dense high veg & & & & & & & 12 & 12 & 100.0 \\
\hline Total & 514 & 144 & 177 & 2 & 3 & 136 & 13 & 989 & \\
\hline Producers accuracy & 100.0 & 86.8 & 89.3 & 0.0 & 0.0 & 96.3 & 92.3 & & \\
\hline
\end{tabular}

Because the purpose of this study was to detect secondary forest succession, the accuracy of the ground and vegetation ALS point classes was extremely important. Overton et al. [100] stated that it is difficult to differentiate LiDAR returns from ground and low vegetation, which may cause misclassifications. On the other hand, Hopkinson et al. [101] demonstrated that grass and herbs do not influence the accuracy of ground point classification. We assume that the classification accuracy requirements for ground points within the ISOK project (1\%) ensured sufficient data reliability.

The method was tested on data collected during the transition between leaf-on and leaf-off conditions because the scanning was completed in mid-October. Moreover, the point clouds were not homogeneous due to the different point densities in the overlapping adjacent stripes. In spite of these constraints, a minimal set of two LiDAR-derived metrics, VHM and VC, accurately detected seven vegetation-related classes that are important for secondary forest succession mapping. Therefore, we assume that the methodology may also work with other LiDAR data that are acquired at a similar density in either the spring (April/May) or fall (October/November), as is the case with most national LiDAR datasets that were collected within the Polish ISOK project. Although our approach differs from several case-specific and site-specific studies that incorporated a large number of input layers to segment and classify land cover [25,31,32,37], it is more universal and has sufficient accuracy.

Two input layers, VHM and VC, were used to segment the study area into homogeneous patches of land. The ESP tool $[86,99]$ was found to be useful for determining the scale parameter; however, the other segmentation parameters were set by trial-and-error because of the lack of an automatic solution. In segmentation we emphasized importance of both vegetation height and canopy cover, as well as regular shapes of land cover objects in a forest-agricultural landscape significantly altered in the past by humans. To tune the segmentation parameters and receive segments resembling real land cover objects as close as possible, extensive preliminary tests in various sites located in the Polish Carpathians were carried out, with a visual inspection of the resulting segmentation against real-world land cover objects visible on high resolution orthophotos. These tests confirmed that the input parameters were suitable for further classification based on the size, shape and homogeneity of the objects. We note, however, that a full automation of segmentation parametrization across a variety of 
landscapes quite likely cannot be achieved, as it has to involve specific land cover patterns in a region in combination with the research goals the segments have to fulfil.

For most of the segments, VHM and VC were sufficient to accurately label the vegetation structure. The proposed classification scheme into sparse or dense and low, medium or high vegetation reflects the slow and gradual process of secondary forest succession well; the overall accuracy (OA) of the classification was $95 \%$, and most of the class-specific accuracies were very high. The results are comparable to those of Falkowski et al. [25] who achieved an overall accuracy of $95 \%$, and better than those of Ewijk et al. [32] $(\mathrm{OA}=90 \%)$ and Martinuzzi et al [37] (kappa $=0.9)$, which is encouraging. Future studies using this workflow are therefore recommended. Potential improvements of classification results may also be achieved using other variables, like intensity [102] or full waveform LiDAR data recommended in several studies on vegetation patterns [103].

We found terrestrial photography to be extremely useful in the accuracy assessment of high-resolution LiDAR-based analysis and propose this solution as a novel way to assess high-resolution, detailed land cover products. Terrestrial photographs can be interpreted easier than orthophotomaps, which are a common source of the ground truth in many studies (e.g., [15]). The oblique imagery provides views that users are familiar with, and horizontal perspective that is unique for geo-data. An indisputable advantage over aerial imagery is that the terrestrial photographs clearly show the relative vegetation height, which is a key factor in secondary forest succession mapping. Vegetation height interpretation from orthophotomaps is difficult or even impossible if no reference objects or shadow cast by trees are visible. On the other hand, terrestrial photographs show a small portion of land, whereas orthophotomaps cover large areas. Moreover, the varying image scale may be an obstacle in precise determination of the land cover patches, but at the same time georeferencing provides accuracy measures by means of known terrain pixel size. In our study, however, the terrestrial photographs were not used for the delineation of vegetation patches, but rather for the assessment of existing ones delineated with ALS data. A compromise solution may be an integration of both terrestrial photographs and orthophotomaps. In this case, orthophotomaps provide spatial extents of homogeneous vegetation patches, while terrestrial photographs support determination of vegetation height. Such an approach may eliminate also problems resulting from the varying image scale. Compared to field-based verification, the use of terrestrial photography may limit the time that is required for field work without compromising its accuracy. Each image that was taken intentionally for accuracy assessment showed a large area of land and therefore included many ground control objects. In this study, 13 photographs (six of them were not taken for use in the accuracy assessment) provided 989 reference polygons, which represented more than $21.3 \%$ of the BDOT10k cropland and grassland area. When carefully georectified, terrestrial photographs also have an advantage over point samples collected in the field because they present the spatial context of the examined features. Photographs that are not taken specifically for accuracy assessment require very careful selection because they do not offer as many advantages and are sometimes not useful in the analysis.

The amount of forest succession on abandoned agricultural land in the Szczawnica commune was found to be significant. Various classes of vegetation were identified on $31 \%$ of the agricultural land, which represents 664 hectares. The patches of arable land and grassland that were covered by secondary succession were mostly located along forest edges, which is consistent with the results of other studies [7,10,17,18,24,51]. In 2014, agricultural land in farms in Małopolska province had an 
average area of 3.95 ha [104]; thus, the area of identified secondary succession in the Szczawnica commune exceeded the size of 168 average farms, which confirms the significance of the agricultural decline in the study area $[71,73]$.

In addition, our findings indicate that the forested area in several locations in the Polish Carpathians may be underestimated. Dense or sparse high and medium vegetation, which may be identified as forests and woodlands, covered $79 \%$ of the analyzed area, which is significantly greater than the officially reported forest cover in the Szczawnica commune (68\%; [19]). This finding confirms a view that the effects of secondary forest succession may exceed the rates of forest increase resulting from the official afforestation plans in Poland [68,105,106]. The outdated census data [68] may consequently produce the statistics that are misleading because the uncontrolled abandonment and forest succession process leads to an increase in the real forest cover and subsequent changes in the forest composition.

\section{Conclusions}

This study highlights the potential of using LiDAR data for mapping forest succession patterns in a mountainous area and usefulness of terrestrial photography in the accuracy assessment. Only two LiDAR-derived metrics, vegetation height model and vegetation cover, supported by national topographic vector data allowed an accurate (95\%) detection of forest succession on abandoned agricultural land. The study was unique in application of terrestrial photographs in the process of accuracy assessment.

Prior to this study, the process of secondary forest succession over the entire region of the Polish Carpathians has not been the subject of scientific research. This study confirmed the significance of contemporary secondary forest succession in the study area and indicated that the proposed method is transferable and may be applied to large-scale studies without major modifications. Future studies should therefore focus on applications of the developed method to larger areas in order to assess various driving factors of land abandonment and secondary succession in the mountain areas.

\section{Acknowledgments}

This research was carried out within the FORECOM project (Forest cover changes in mountainous regions - drivers, trajectories and implications, PSRP-008/2010), which was supported by a grant from Switzerland through the Swiss contribution to the enlarged European Union.

\section{Author Contributions}

Natalia Kolecka and Jacek Kozak conceived of and designed the experiments. Natalia Kolecka performed the analysis of the data with the advice of Jacek Kozak, Dominik Kaim and Monika Dobosz. Natalia Kolecka and Jacek Kozak performed interpretation of the data. Natalia Kolecka, Jacek Kozak, Dominik Kaim, Monika Dobosz, Christian Ginzler and Achilleas Psomas discussed the basic structure of the manuscript, and Natalia Kolecka finished the first draft. Jacek Kozak reviewed and edited the draft. All authors, discussed, commented the draft. All authors read and approved the submitted manuscript, agreed to be listed and accepted the version for publication. 


\section{Conflicts of Interest}

The authors declare no conflict of interest.

\section{References}

1. Hansen, M.C.; Stehman, S.V.; Potapov, P.V. Quantification of global gross forest cover loss. Proc. Natl. Acad. Sci. USA 2010, 107, 8650-8655.

2. FAO. Global Forest Resources Assessment 2010. Main Report; Food and Agriculture Organization of the United Nations: Rome, Italy, 2010; p. 378.

3. Fuchs, R.; Herold, M.; Verburg, P.H.; Clevers, J.G.P.W. A high-resolution and harmonized model approach for reconstructing and analysing historic land changes in Europe. Biogeosciences 2013, 10, 1543-1559.

4. Fuchs, R.; Herold, M.; Verburg, P.H.; Clevers, J.G.P.W.; Eberle, J. Gross changes in reconstructions of historic land cover/use for Europe between 1900 and 2010. Glob. Chang. Biol. 2015, 21, 299-313.

5. Verburg, P.H.; Overmars, K.P. Combining top-down and bottom-up dynamics in land use modeling: exploring the future of abandoned farmlands in Europe with the Dyna-CLUE model. Landsc. Ecol. 2009, 24, 1167-1181.

6. Václavík, T.; Rogan, J. Identifying trends in land use/land cover changes in the context of post-socialist transformation in Central Europe: A case study of the Greater Olomouc Region, Czech Republic. GISci. Remote Sens. 2009, 46, 54-76.

7. Munteanu, C.; Kuemmerle, T.; Boltiziar, M.; Butsic, V.; Gimmi, U.; Kaim, D.; Király, G.; Konkoly-Gyuró, É.; Kozak, J.; Lieskovský, J.; et al. Forest and agricultural land change in the Carpathian region-A meta-analysis of long-term patterns and drivers of change. Land Use Policy 2014, 38, 685-697.

8. Pazúr, R.; Lieskovský, J.; Feranec, J.; Ot’ahel', J. Spatial determinants of abandonment of large-scale arable lands and managed grasslands in Slovakia during the periods of post-socialist transition and European Union accession. Appl. Geogr. 2014, 54, 118-128.

9. MacDonald, D.; Crabtree, J. .; Wiesinger, G.; Dax, T.; Stamou, N.; Fleury, P.; Gutierrez Lazpita, J.; Gibon, A. Agricultural abandonment in mountain areas of Europe: Environmental consequences and policy response. J. Environ. Manag. 2000, 59, 47-69.

10. Kozak, J. Forest Cover Change in the Western Carpathians in the Past 180 Years. Mt. Res. Dev. 2003, 23, 369-375.

11. Feranec, J.; Ot'ahel', J. Land cover changes in Slovakia in the period 1970-2000. Geogr. Cas. 2008, 60, 113-128.

12. Sitko, I.; Troll, M. Timberline Changes in Relation to Summer Farming in the Western Chornohora (Ukrainian Carpathians). Mt. Res. Dev. 2008, 28, 263-271.

13. Gerard, F.; Petit, S.; Smith, G.; Thomson, A.; Brown, N.; Manchester, S.; Wadsworth, R.; Bugar, G.; Halada, L.; Bezak, P.; et al. Land cover change in Europe between 1950 and 2000 determined employing aerial photography. Prog. Phys. Geogr. 2010, 34, 183-205. 
14. Stefanski, J.; Chaskovskyy, O.; Waske, B. Mapping and monitoring of land use changes in post-Soviet western Ukraine using remote sensing data. Appl. Geogr. 2014, 55, 155-164.

15. Wezyk, P.; de Kok, R. Automatic mapping of the dynamics of forest succession on abandoned parcels in south Poland. In Hrsg. Angewandte Geoinformatik zum 17. AGIT-Symposium Salzburg 2005; Strobl, J., Blaschke, T., Griesebner, G., Eds.; Herbert Wichman Verlag: Heidelberg, Germany, 2005; pp. 774-779.

16. Kuemmerle, T.; Hostert, P.; Radeloff, V.C.; Linden, S.; Perzanowski, K.; Kruhlov, I. Cross-border Comparison of Post-socialist Farmland Abandonment in the Carpathians. Ecosystems 2008, 11, 614-628.

17. Kozak, J. Reforesting landscapes. In Reforesting Landscapes Linking Pattern and Process (Landscape Series); Nagendra, H., Southworth, J., Eds.; Springer: Dordrecht, The Netherlands, 2010; Volume 10, pp. 253-273.

18. Hostert, P.; Kuemmerle, T.; Prishchepov, A.; Sieber, A.; Lambin, E.F.; Radeloff, V.C. Rapid land use change after socio-economic disturbances: the collapse of the Soviet Union versus Chernobyl. Environ. Res. Lett. 2011, 6, 045201.

19. PSR. Powszechny Spis Rolny 2010. Raport z Wyników Województwa Małopolskiego; Urząd Statystyczny w Krakowie: Kraków, Poland, 2011.

20. PSR. Powszechny Spis Rolny 2010. Raport z Wyników Województwa Podkarpackiego; Urząd Statystyczny w Rzeszowie: Rzeszów, Poland, 2011.

21. Ostafin, K. Zmiany Granicy Rolno-Leśnej w Środkowej Część Beskidu Średniego od Połowy XIX Wieku do 2005 Roku; Wydawnictwo Uniwersytetu Jagiellońskiego: Kraków, Poland, 2009.

22. Kaim, D. Wykorzystanie Powtórzonej Fotografii Naziemnej w Badaniach Zmian Pokrycia Terenu Wybranych Obszarów Karpat Polskich. Ph.D. Thesis, Jagiellonian University, Kraków, Poland, June 2014.

23. Risch, A.C. Above- and Belowground Patterns and Processes Following Land Use Change in Subalpine Conifer Forests of the Central European Alps. Ph.D. Thesis, Dissertation No. 15368, Swiss Federal Institute of Technology Zurich, Zurich, Switzerland, 2004.

24. Griffiths, P.; Kuemmerle, T.; Baumann, M.; Radeloff, V.C.; Abrudan, I.V.; Lieskovsky, J.; Munteanu, C.; Ostapowicz, K.; Hostert, P. Forest disturbances, forest recovery, and changes in forest types across the Carpathian ecoregion from 1985 to 2010 based on Landsat image composites. Remote Sens. Environ. 2014, 151, 72-88.

25. Falkowski, M.J.; Evans, J.S.; Martinuzzi, S.; Gessler, P.E.; Hudak, A.T. Characterizing forest succession with lidar data: An evaluation for the Inland Northwest, USA. Remote Sens. Environ. 2009, 113, 946-956.

26. Kane, V.R.; McGaughey, R.J.; Bakker, J.D.; Gersonde, R.F.; Lutz, J.A.; Franklin, J.F. Comparisons between field- and LiDAR-based measures of stand structural complexity. Can. J. For. Res. 2010, 40, 761-773.

27. Blatt, S.E.; Crowder, A.; Harmsen, R. Secondary Succession in Two South-Eastern Ontario Old-Fields. Plant Ecol. 2005, 177, 25-41.

28. Townshend, J.R.; Masek, J.G.; Huang, C.; Vermote, E.F.; Gao, F.; Channan, S.; Sexton, J.O.; Feng, M.; Narasimhan, R.; Kim, D.; et al. Global characterization and monitoring of forest cover using Landsat data: Opportunities and challenges. Int. J. Digit. Earth 2012, 5, 373-397. 
29. Pflugmacher, D.; Cohen, W.B.; Kennedy, R.E.; Yang, Z. Using Landsat-derived disturbance and recovery history and LiDAR to map forest biomass dynamics. Remote Sens. Environ. 2013, 151, 124-137.

30. Villarreal, M.; Norman, L.; Webb, R.; Turner, R. Historical and contemporary geographic data reveal complex spatial and temporal responses of vegetation to climate and land stewardship. Land 2013, 2, 194-224.

31. Maier, B.; Tiede, D.; Dorren, L. Characterising mountain forest structure using landscape metrics on LiDAR-based canopy surface models. In Object-Based Image Analysis; Blaschke, T., Lang, S., Hay, G.J., Eds.; Lecture Notes in Geoinformation and Cartography; Springer: Berlin/Heidelberg, Germany, 2008; pp. 625-643.

32. Van Ewijk, K.Y.; Treitz, P.M.; Scott, N.A. Characterizing forest succession in Central Ontario using LiDAR-derived indices. Photogramm. Eng. Remote Sens. 2011, 77, 261-269.

33. Eysn, L.; Hollaus, M.; Schadauer, K.; Pfeifer, N. Forest delineation based on airborne LiDAR data. Remote Sens. 2012, 4, 762-783.

34. Wulder, M.A.; White, J.C.; Nelson, R.F.; Næsset, E.; Ørka, H.O.; Coops, N.C.; Hilker, T.; Bater, C.W.; Gobakken, T. LiDAR sampling for large-area forest characterization: A review. Remote Sens. Environ. 2012, 121, 196-209.

35. Xiao, W.E.N. Detecting changes in trees using multi-temporal airborne LiDAR point clouds. Master's Thesis, University of Twente, Enschede, The Nederlands, 2012; p. 49.

36. Meyer, V.; Saatchi, S.S.; Chave, J.; Dalling, J.W.; Bohlman, S.; Fricker, G.A.; Robinson, C.; Neumann, M.; Hubbell, S. Detecting tropical forest biomass dynamics from repeated airborne lidar measurements. Biogeosciences 2013, 10, 5421-5438.

37. Martinuzzi, S.; Gould, W.A.; Vierling, L.A.; Nelson, R.F. Quantifying Tropical dry forest type and succession: Substantial Improvement with LiDAR. Biotropica 2012, 45, 135-146.

38. Asmare, M.F. Airborne LiDAR data and VHR WorldView Satellite Imagery to Support Community Based Forest Certification in Chitwan, Nepal. MSc Thesis, University of Twente, Enschede, The Nederlands, 2013.

39. Blaschke, T.; Burnett, C.; Pekkarinen, A. Image segmentation methods for object-based analysis and classification. In Remote Sensing Image Analysis: Including the Spatial Domain; de Jong, S.M., van der Meer, F.D., Eds.; Springer: Dordrecht, The Netherlands, 2004; pp. 211-236.

40. Hay, G.J.; Castilla, G.; Wulder, M.A.; Ruiz, J.R. An automated object-based approach for the multiscale image segmentation of forest scenes. Int. J. Appl. Earth Obs. Geoinf. 2005, 7, 339-359.

41. Blaschke, T.; Hay, G.J.; Kelly, M.; Lang, S.; Hofmann, P.; Addink, E.; Feitosa, R.Q.; van der Meer, F.; van der Werff, H.; van Coillie, F.; et al. Geographic Object-Based Image Analysis-Towards a new paradigm. ISPRS J. Photogramm. Remote Sens 2014, 87, 180-191.

42. Baatz, M.; Hoffmann, C.; Willhauck, G. Progressing from object-based to object-oriented image analysis. In Object-Based Image Analysis; Blaschke, T., Lang, S., Hay, G.J., Eds.; Lecture Notes in Geoinformation and Cartography; Springer: Berlin/Heidelberg, Germany, 2008; pp. 29-42.

43. Kim, Y.; Chang, A.; Kim, Y.; Eo, Y. Estimation of forest biomass based on segmentation using. In Proceedings of ASPRS 2012 Annual Conference, Sacramento, CA, USA, 19-23 March 2012.

44. Jakubowski, M.; Li, W.; Guo, Q.; Kelly, M. Delineating individual trees from LiDAR data: A comparison of vector- and raster-based segmentation approaches. Remote Sens. 2013, 5, 4163-4186. 
45. Van Aardt, J.A.N.; Wynne, R.H.; Scrivani, J.A. LiDAR-based mapping of forest volume and biomass by taxonomic group using structurally homogenous segments. Photogramm. Eng. Remote Sens. 2008, 74, 1033-1044.

46. Diedershagen, O.; Koch, B.; Weinacker, H. Automatic segmentation and characterisation of forest stand parameters using airborne LiDAR data, multispectral and FoGIS data. In Proceedings of the ISPRS Working Group VIII/2, Freiburg, Germany, 3-6 October 2004; pp. $208-212$.

47. Hellesen, T.; Matikainen, L. An object-based approach for mapping shrub and tree cover on grassland habitats by use of LiDAR and CIR orthoimages. Remote Sens. 2013, 5, 558-583.

48. Höfle, B.; Hollaus, M.; Lehner, H.; Pfeifer, N.; Wagner, W. Area-based parameterization of forest structure using full-waveform airborne laser scanning data. In Proceedings of SilviLaser 2008, 8th International Conference on LiDAR Applications in Forest Assessment and Inventory; Hill, R., Rosette, J., Suárez, J., Eds.; Heriot-Watt University: Edinburgh, UK, 2008; pp. 1-9.

49. Dupuy, S.; Laine, G.; Tormos, T. OBIA for combining LiDAR and multispectral data to characterize forested areas and land cover in tropical region. In Proceedings of the 4th International Conference on Geographic Object-Based Image Analysis (GEOBIA), Rio de Janeiro, Brazil, 7-9 May 2012; pp. 279-285.

50. Massada, A.B.; Kent, R.; Blank, L.; Perevolotsky, A. Automated segmentation of vegetation structure units in a Mediterranean landscape. Int. J. Remote Sens. 2012, 33, 37-41.

51. Szostak, M.; Wezyk, P.; Tompalski, P. Aerial orthophoto and airborne laser scanning as monitoring tools for land cover dynamics: A case study from the Milicz Forest District (Poland). Pure Appl. Geophys. 2013, 171, 857-866.

52. Gimmi, U. Applications of monoplotting techique in land use change studies. In Proceedings of Landscape study with Historical Photographs through Monoplotting-Workshop, Corzoneso, Switzerland, 27-28 June 2014.

53. Zier, J.L.; Baker, W.L. A century of vegetation change in the San Juan Mountains, Colorado: An analysis using repeat photography. For. Ecol. Manage. 2006, 228, 251-262.

54. Hendrick, L.E.; Copenheaver, C.A. Using Repeat Landscape Photography to Assess Vegetation Changes in Rural Communities of the Southern Appalachian Mountains in Virginia, USA. Mt. Res. Dev. 2009, 29, 21-29.

55. Kaim, D.; Kolecka, N. Zmiany pokrycia terenu w Tatrach Polskich określone na podstawie powtorzonej fotografii naziemnej. Pr. Geogr. 2010, 123, 31-45.

56. Webb, R.H. Repeat Photography: Methods and Applications in the Natural Sciences; Island Press: Washington, DC, USA, 2010; Volume 15, p. 392.

57. Aschenwald, J.; Leichter, K.; Tasser, E.; Tappeiner, U. Spatio-temporal landscape analysis in mountainous terrain by means of small format photography: A methodological approach. IEEE Trans. Geosci. Remote Sens. 2001, 39, 885-893.

58. Corripio, J.G. Snow surface albedo estimation using terrestrial photography. Int. J. Remote Sens. 2004, 25, 5705-5729.

59. Fluehler, M.; Niederoest, J.; Akca, D.; Zurich, E.T.H.; Vi, C.; Vi, W.G.V.I. Development of an Educational Software System; ETH Zurich, Institute of Geodesy and Photogrammetry: Zurich, Switzerland, 2005. 
60. Meire, E.; Frankl, A.; de Wulf, A.; Haile, M.; Deckers, J.; Nyssen, J. Land use and cover dynamics in Africa since the nineteenth century: warped terrestrial photographs of North Ethiopia. Reg. Environ. Chang. 2012, 13, 717-737.

61. Bozzini, C.; Conedera, M.; Krebs, P. A new tool for obtaining cartographic georeferenced data from single oblique photos. In Proceedings of the XXIIIrd International CIPA Symposium, Prague, Czech Republic, 12-16 September 2011; p. 6.

62. Kolecka, N. Terrestrial Photography as Possible Data Source for Geographic Information Systems. Arch. Fotogram. Kartogr. i Teledetekcji 2010, 21, 159-168.

63. Chrustek, P.; Kolecka, N.; Bühler, Y. Obtaining Snow Avalanche Information by Means of Terrestrial Photogrammetry-Evaluation of a New Approach. In The Carpathians: Integrating Nature and Society towards Sustainability. Environmental Science and Engineering; Kozak, J., Ostapowicz, K., Bytnerowicz, A., Wyzga, B., Eds.; Springer: Berlin/Heidelberg, Germany, 2013; pp. 597-613.

64. Chrustek, P.; Kolecka, N.; Bühler, Y. Snow avalanches mapping_Evaluation of a new approach. In Proceedings of the International Snow Science Workshop 2013, Grenoble-Chamonix Mont Blanc, France, 7-11 October 2013; Naaim-Bouvet, F., Durand, Y., Lambert, R., Eds.; ANENA: Grenoble, France, 2013; pp. 750-755.

65. Bozzini, C.; Conedera, M.; Krebs, P. New Monoplotting Tool to Extract Georeferenced Vector Data and Orthorectified Raster Data from Oblique Non-Metric Photographs. Int. J. Herit. Digit. Era 2012, 1, pp. 500-518.

66. Steiner, L. Reconstruction of Glacier States from Geo-Referenced, Historical Postcards. Master' Thesis, ETH Zurich, Zurich, Switzerland, October 2011.

67. Wiesmann, S.; Steiner, L.; Pozzi, M.; Bozzini, C.; Bauder, A.; Hurni, L. Reconstructing Historic Glacier States Based on Terrestrial Oblique Photographs. In Proceedings of the AutoCarto International Symposium on Automated Cartography, Columbus, OH, USA, 16-18 September 2012.

68. Szwagrzyk, J. Forest succession on abandoned farmland; current estimates, forecasts and uncertainties. Sylwan 2004, 4, 53-59.

69. Frączek, M.; Zborowska, M. Secondary forest succession in the non-existing village Świerzowa Ruska in the Magurski National Park. Rocz. Bieszczadzkie 2010, 18, 112-128.

70. GUS. Area and Population in the Territorial Profile in 2014; Central Statistical Office: Warszawa, Poland, 2014.

71. Kaim, D. Zmiany pokrycia terenu na pograniczu polsko-słowackim na przykładzie Małych Pienin. Przegląd Geogr. 2009, 81, 93-106.

72. Jaguś, A.; Kulpa, R.; Rzętała, M. Zmiany użytkowania terenu i wód powierzchniowych w Pieninach. Pieniny-Przyr. i Człowiek 2006, 9, 143-155.

73. Dec, M.; Kaszta, Ż.; Korzeniowska, K.; Podsada, A.; Sobczyszyn-Żmudź, S.; Wójtowicz, A.; Zimna, E.; Ostapowicz, K. Land Use Change in Three Carpathian Communities (Niedźwiedź, Szczawnica and Trzciana) in the Second Part of the 20th Century. Arch. Fotogram. Kartogr. $i$ Teledetekcji 2009, 20, 81-89.

74. ISOK ISOK - IT System of the Country's Protection. Available online: http://www.isok.gov.pl/en/ (accessed on 7 October 2014). 
75. Woźniak, P. Wykorzystanie danych przestrzennych do opracowania map zagrożenia powodziowego i map ryzyka powodziowego. In Proceedings of the Conference Regarding Development and Use of the Flood Hazard Maps and Flood Risk Maps, Warszawa, Poland, 24 June 2014.

76. ASPRS. LAS Specification. Version 1.2; The American Society for Photogrammetry \& Remote Sensing: Bethesda, MD, USA, 2008; pp. 1-13.

77. Axelsson, P. Processing of laser scanner data-Algorithms and applications. ISPRS J. Photogramm. Remote Sens. 1999, 54, 138-147.

78. Meng, X.; Currit, N.; Zhao, K. Ground filtering algorithms for airborne LiDAR data: A review of critical issues. Remote Sens. 2010, 2, 833-860.

79. MSWiA. Rozporządzenie MSWiA z Dnia 17 Listopada 2011 r. w Sprawie Bazy Danych Obiektów Topograficznych Oraz Bazy Danych Obiektów Ogólnogeograficznych, a Także Standardowych Opracowań Kartograficznych; Ministry of the Interior and Administration (Poland): Warszawa, Poland, 2011.

80. Kolecka, N.; Kozak, J.; Dobosz, M.; Psomas, A. Land Abandonment Mapping in the Polish Carpathians. South-East. Eur. J. Earth Obs. Geomatics. 2014, 3, 103-108.

81. Jennings, S.B.; Brown, N.D.; Sheil, D. Assessing forest canopies and understorey illumination: canopy closure, canopy cover and other measures. Forestry 1999, 72, 59-73.

82. Smith, A.M. S.; Falkowski, M.J.; Evans, J.S.; Robinson, A.P. A cross-comparison of field, spectral, and LiDAR estimates of forest canopy cover. Can. J. Remote Sens. 2009, 35, 447-459.

83. ESRI LAS Specification. Version 1.2. Available online: http://www.esri.com/ (accessed on 7 October 2014).

84. ERDAS ERDAS Imagine. Hexagon Geospatial. Available online: http://www.hexagongeospatial.com/ (accessed on 7 October 2014).

85. Trimble eCognition. Available online: http://www.ecognition.com/ (accessed on 7 October 2014).

86. Drăguţ, L.; Tiede, D.; Levick, S.R. ESP: A tool to estimate scale parameter for multiresolution image segmentation of remotely sensed data. Int. J. Geogr. Inf. Sci. 2010, 24, 859-871.

87. Drăguţ, L.; Eisank, C.; Strasser, T. Local variance for multi-scale analysis in geomorphometry. Geomorphology 2011, 130, 162-172.

88. Breiman, L.; Friedman, J.; Stone, C.J.; Olshen, R.A. Classification and Regression Trees; Chapman \& Hall/CRC: Belmont, CA, USA, 1984.

89. Congalton, R.; Green, K. Assessing the Accuracy of Remotely Sensed Data: Principles and Practices; CRC/Taylor \& Francis: Boca Raton, FL, USA, 2009; p. 183.

90. Radoux, J.; Bogaert, P.; Defourny, P. Overall Accuracy Estimation for Geographic Object-based Image Classification. In Proceedings of the Ninth International Symposium on Spatial Accuracy Assessment in Natural Resources and Environmental Sciences, Leicester, UK, 20-23 July 2010; pp. 17-20.

91. Hernando, A.; Tiede, D.; Albrecht, F.; Lang, S.; García-Abril, A. Novel parameters for evaluating the spatial and thematic accuracy of land cover maps. In Proceedings of the 4th GEOBIA, Rio de Janeiro, Brazil, 7-9 May 2012; pp. 613-617.

92. Olofsson, P.; Foody, G.M.; Herold, M.; Stehman, S.V.; Woodcock, C.E.; Wulder, M.A. Good practices for estimating area and assessing accuracy of land change. Remote Sens. Environ. 2014, $148,42-57$. 
93. Whiteside, T.G.; Maier, S.W.; Boggs, G.S. Area-based and location-based validation of classified image objects. Int. J. Appl. Earth Obs. Geoinf. 2014, 28, 117-130.

94. Schöpfer, E.; Lang, S.; Albrecht, F. Object-fate analysis: Spatial relationships for the assessment of object transition and correspondence. In Object-Based Image Analysis; Blaschke, T., Lang, S., Hay, G.J., Eds.; Lecture Notes in Geoinformation and Cartography; Springer: Berlin/Heidelberg, Germany, 2008; pp. 785-801.

95. Kraus, K. Photogrammetry. Geometry from Images and Laser Scans, 2nd ed.; Walter de Gruyter: Berlin, Germany, 2007.

96. Congalton, R.G. A Review of Assessing the Accuracy of Classifications of Remotely Sensed Data. Remote Sens. Environ. 1991, 46, 35-46.

97. Schöpfer, E.; Lang, S. Object-fate analysis - A virtual overlay method for the categorization of object transition and object-based accuracy assessment. Int. Arch. Photogramm. Remote Sens. Spat. Inf. Sci. 2006, 36, C42.

98. Lang, S.; Schopfer, E.; Langanke, T. Combined object-based classification and manual interpretation-Synergies for a quantitative assessment of parcels and biotopes. Geocarto Int. 2009, 24, 99-114.

99. Drăguţ, L.; Csillik, O.; Eisank, C.; Tiede, D. Automated parameterisation for multi-scale image segmentation on multiple layers. ISPRS J. Photogramm. Remote Sens. 2014, 88, 119-127.

100. Overton, I.C.; Siggins, A.; Gallant, J.C.; Penton, D.; Byrne, G. Flood Modelling and Vegetation Mapping in Large River Systems. In Laser Scanning for the Environmental Sciences; Heritage, G.L., Large, A.R.G., Eds.; Wiley-Blackwell: Oxford, UK, 2009; pp. 220-244.

101. Hopkinson, C.; Chasmer, L.E.; Sass, G.; Creed, I.F.; Sitar, M.; Kalbfleisch, W.; Treitz, P. Vegetation class dependent errors in lidar ground elevation and canopy height estimates in a boreal wetland environment. Can. J. Remote Sens. 2005, 31, 191-206.

102. Yan, W.Y.; Shaker, A.; El-Ashmawy, N. Urban land cover classification using airborne LiDAR data: A review. Remote Sens. Environ. 2015, 158, 295-310.

103. Höfle, B.; Hollaus, M.; Hagenauer, J. Urban vegetation detection using radiometrically calibrated small-footprint full-waveform airborne LiDAR data. ISPRS J. Photogramm. Remote Sens. 2012, 67, 134-147.

104. ARMIR Średnia powierzchnia gospodarstwa. Ogłoszenie Prezesa Agencji Restrukturyzacji i Modernizacji Rolnictwa. Available online: http://www.arimr.gov.pl/dla-beneficjenta/sredniapowierzchnia-gospodarstwa.html (accessed on 18 Feburary 2015).

105. Krajowy Program Zwiększania Lesistości. Aktualizacja 2003 r.; Polish Minister of Environment: Warszawa, Poland, 2003.

106. Informacja o Stanie Lasów Oraz o Realizacji "Krajowego Programu Zwiększania Lesistości” w 2012 Roku; Polish Minister of Environment: Warszawa, Poland, 2013.

(C) 2015 by the authors; licensee MDPI, Basel, Switzerland. This article is an open access article distributed under the terms and conditions of the Creative Commons Attribution license (http://creativecommons.org/licenses/by/4.0/). 